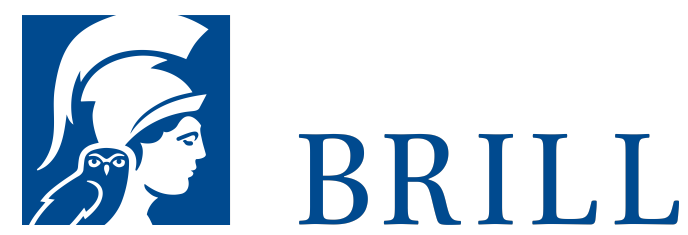

\title{
Dichtung als "Gesang"
}

Hölderlins "Wie wenn am Feiertage..." im Kontext der Schriften zur Philosophie und Poetik 1795-1802

Author: Jürg Friedrich

Immer wieder von neuem artikuliert Hölderlin zwischen 1795 und 1802 ein ihm eigenes radikal neues Dichtungsprojekt. Unter dem Titel "Gesang“ verbindet sich darin die Hoffnung auf eine umfassende politische und religiöse Erneuerung der (zwischen)menschlichen Verhältnisse mit einer neuen, noch zu schaffenden, kommenden Dichtung. Diese Studie spürt den in Hölderlins Texten antizipierten Momenten des „Gesangs“ nach und widmet sich dabei vor allem Hölderlins Hymnenfragment „Wie wenn am Feiertage....". Durch eine Fülle von Querverweisen auf Hölderlins übriges lyrisches und dramatisches Werk und besonders durch zwei theoretische Kapitel zu den philosophischen und poetologischen Texten Hölderlins gelangt die Studie zu einer Charakterisierung von Hölderlins poetischer Sprache als einem durchgängig prozessualen Sprachgeschehen.

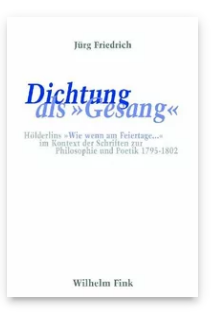

Pages: 242

Seiten

Language:

German

Subjects:

German,

Literature and

Cultural Studies

Publisher: Brill |

Fink

E-Book (PDF)

Released online:

29 Jan 2020

ISBN: 978-3-

8467-4398-о

List price

USD $\$ 63.00$

Paperback

Publication date:

24 Oct 2007

ISBN: 978-3-

7705-4398-4

List price

USD $\$ 63.00$ 
For more information see brill.com

Order information: Order online at brill.com +44330 333 0049 | customerservices@brill.com Submission information: brill.com/authors

Titles published by Brill | Fink, Brill | mentis or Brill | Schöningh: +49(o)715413279216| brill@brocom.de 